\begin{tabular}{|l|l|l|}
\hline \multicolumn{2}{|c|}{ PublisherInfo } \\
\hline \hline PublisherName & $:$ & BioMed Central \\
\hline \hline PublisherLocation & $:$ & London \\
\hline \hline PublisherImprintName & $:$ & BioMed Central \\
\hline \hline
\end{tabular}

\title{
Structural proteomics boost
}

\begin{tabular}{|l|c|l||}
\hline \multicolumn{2}{|c|}{ ArticleInfo } \\
\hline \hline ArticleID & $:$ & 4966 \\
\hline \hline ArticleDOI & $:$ & $10.1186 /$ gb-spotlight-20040618-01 \\
\hline \hline ArticleCitationID & $:$ & spotlight-20040618-01 \\
\hline \hline ArticleSequenceNumber & $:$ & 29 \\
\hline \hline ArticleCategory & $:$ & Research news \\
\hline ArticleFirstPage & $:$ & 1 \\
\hline \hline ArticleLastPage & $:$ & 2 \\
\hline \hline & & RegistrationDate : 2004-6-18 \\
\hline ArticleHistory & $:$ & OnlineDate \\
\hline \hline ArticleCopyright & $:$ & BioMed Central Ltd2004-6-18 \\
\hline \hline ArticleGrants & $:$ & \\
\hline \hline ArticleContext & $:$ & 130595511 \\
\hline \hline
\end{tabular}




\section{Genome Biology Editorial Staff}

Email: editorial@genomebiology.com

The UK Biotechnology and Biological Sciences Research Council (BBSRC) has announced two new research programs in structural proteomics that together will receive $£ 11.5 \mathrm{~m}$ under the Structural Proteomics of Rational Targets (SPoRT) Initiative.

The two programs are the Membrane Protein Structure Initiative (MPSI), a consortium of experienced membrane research groups at universities and institutes across the UK, which has been awarded over $£ 6.8 \mathrm{~m}$, and the Structural Proteomics Facility, established by the Universities of Dundee, Glasgow, St Andrews and Warwick, which will receive over $£ 4.6 \mathrm{~m}$.

MPSI, led by the University of Glasgow, aims to develop strategies for the efficient production, crystallization and structure determination of proteins that are located in the membranes of cells. Over $30 \%$ of human genes produce membrane proteins and more than half of the drugs in current use act on membrane proteins, so they are prime targets for structural studies - but their structures are particularly difficult to determine.

The Structural Proteomics Facility will fund an inclusive and multidisciplinary scientific programme that aims to apply high-throughput methods to carefully selected microbial proteins, including those involved in natural product synthesis (many of the drugs used today are derived from natural products), enzymes that are required by microbes to cause disease, and proteins involved in the life-cycle of viruses. This information will be important in understanding and combating pathogenic microorganisms.

The Chief Executive of the BBSRC, Professor Julia Goodfellow, said "The sequencing of a large number of genomes has provided us with a wealth of information but has raised many challenging questions about the function of proteins within cells. These are exciting programmes aimed at understanding the function of important groups of proteins at the molecular level."

\section{References}

1. Biotechnology and Biological Sciences Research Council, [http://www.bbsrc.ac.uk/] 